The Journal of Animal \& Plant Sciences, 30(5): 2020, Page: 1178-1186

ISSN (print): 1018-7081; ISSN (online): 2309-8694

\title{
DIFFERENT IRRIGATION SYSTEMS AFFECT THE YIELD AND WATER USE EFFICIENCYOF KINNOW MANDARIN (CITRUS RETICULATA BLANCO.)
}

\author{
A. Raza ${ }^{1 *}$, M. A. Zaka ${ }^{2}$, T. Khurshid ${ }^{3}$, M. A. Nawaz ${ }^{4}$, W. Ahmed ${ }^{5}$, and M. B. S. Afzal ${ }^{1}$ \\ ${ }^{1}$ Citrus Research Institute, Sargodha, Pakistan; ${ }^{2}$ Soil Salinity Research Institute, Pindi Bhattian, Pakistan \\ ${ }^{3}$ NSW Department of Primary Industries, 1998 Silver City Highway, Dareton, Australia. \\ ${ }^{4}$ Department of Horticulture, College of Agriculture, University of Sargodha, Sargodha, Pakistan. \\ ${ }_{5}^{5}$ Pakistan Agriculture Technology Transfer Activity (PAATA), CNFA, USAID, Lahore, Pakistan. \\ ${ }^{*}$ Corresponding author's email: razacri340@gmail.com
}

\begin{abstract}
Considering the scarce water resources, low average yield of citrus fruits, and haphazard irrigation system adopted in Pakistan; a study was conducted on 25 year old Kinnow mandarin plants grafted onto Rough lemon (Citrus jambhiri Lush.) during 2011-2015. In this study four modes of irrigation that includes drip irrigation (DI), full cover sprinkler (FCS), strip cover sprinkler (SCS) and traditional flood irrigation (TFI) were used. The yield, quality and water use efficiency (WUE) were evaluated. This study was conducted at Citrus Research Institute (CRI), Sargodha, Pakistan. To monitor the moisture level in the soil, tensiometers were installed in each block at the depth of 30,60 and $90 \mathrm{~cm}$ in the root zone. A flume meter was used to measure the total quantity of water applied under flood irrigation system. The Kinnow plants growing under TFI system produced a fruit yield of $26.12 \mathrm{t} \mathrm{ha}^{-1}\left(687\right.$ fruits tree ${ }^{-1}$ and $\left.104.55 \mathrm{kgtree}^{-1}\right)$ and WUE was only $2.29 \mathrm{~kg} \mathrm{~m}^{-3}$, however $40.46 \%$ higher yield (1288 fruitstree ${ }^{-1}$ and $\left.181 \mathrm{kgtree}^{-1}\right)$ was obtained from plants grown under DI system compared with TFI and WUE was $4.85 \mathrm{kgm}^{-3}$. The $55 \%$ water saving was attained using DI compared with TFI. Similarly, significantly higher yield of 28.45\% (1029 fruit tree ${ }^{-1}$ and $\left.151 \mathrm{kgtre}^{-1}\right)$ and 27.19\% (1045 fruit tree ${ }^{-1}$ and $147.92 \mathrm{kgtree}^{-1}$ was obtained by using FCS and SCS, respectively compared with TFI, and WUE in FCS and SCS system was $3.03 \mathrm{~kg} \mathrm{~m}^{-3}$ and $3.35 \mathrm{~kg} \mathrm{~m}^{-3}$, respectively as compared with TFI $\left(2.29 \mathrm{~kg} \mathrm{~m}^{-3}\right)$. It is concluded that DI is superior in terms of higher yield and WUE therefore for Kinnow growers DI is recommended to get higher yield and enhance the WUE.
\end{abstract}

Keywords: citrus, irrigation methods, high efficiency irrigation systems, yield, fruit quality.

https://doi.org/10.36899/JAPS.2020.5.0135

Published online June 25, 2020

\section{INTRODUCTION}

Citrus is extensively cultivated $(9.276$ million hectares) fruit crop across the world with an annual production of 146.60 million ton (AMIS, 2017). Citrus is also the leading fruit crop of Pakistan. Citrus orchards are prevalent over an area of 0.195 million hectares with an annual production of 2.267 million tons (FAO, 2017). Kinnow is the leading citrus cultivar in Pakistan and its share in the total citrus fruit production exceeds $95 \%$ (Fateh et al., 2017; Nawaz et al., 2008). In Pakistan, total share of fruit crops in earning foreign exchange is 399.51 million US dollars (1.72\%); out of this 68.30 million US dollars are earned by the export of Kinnow (TDAP, 2019)

Kinnow is hybrid of two citrus cultivars; a King (Citrus nobilis) $\times$ Willow Leaf (Citrus deliciosa) and belongs to family Rutaceae (Khalid, 2013). In Pakistan, district Sargodha is very popular for the production of superior quality of Kinnow fruit. Rough lemon is used as a rootstock predominantly in Punjab, Pakistan on a commercial scale (Ahmed et al., 2007; Khalid et al., 2012; Shireen et al., 2018).
The flood irrigation system is adopted by farmers on large scale to irrigate the Kinnow orchard. Flood irrigation system is considered sub-economical because of maximum water losses and it is reported to damage citrus plants being the source of disease inoculum or carries disease inoculum from diseased to healthy plants (Savita and Nagpal, 2012). In the near future, the irrigated agriculture need two-third increase in food production to meet the food requirement of increasing population (Rockström et al., 2007).

According to a report, Pakistan is facing severe shortage of water, passed the water stressed level and soon may be listed into water scarce country. In Asia, Pakistan is being considered as worst performer in terms of water use (Mirjat et al., 2011). Citrus is not considered a water dependent crop but frequent irrigation is important for its proper growth and development and quality fruit (Carr, 2012). According to a report, peach trees irrigated frequently by drip irrigation performed better and had an improved fruit size and yield compared with other methods of irrigation. Frequent irrigation helped to maintain the high water status in peach plants, thus improved plant performance (Bryla et al. (2005). 
Although flood irrigation is considered as a low cost and easy method of irrigation to orchards but it causes water losses, leaching of essential nutrients from the root zone and transfer of soil borne fungal diseases (Singh and Sharma, 2012); Shirgure et al., 2000). Traditional irrigation systems such as overhead sprinkler and flooding system keep the soil, leaves and tree's stem wet for a longer period of time which may promote infection by molds and fungi. Flood irrigation consumes extra water while the drip irrigation technique slowly supplies measured quantity of water to the root zone of the plants, only (Kumar, 2016). Pressurized irrigation system such as drip and sprinklers are modern methods of irrigation through which a control and desired amount of water is applied to the orchard. Besides water saving, the drip system also increases the fruit yield of citrus fruits (Morgan et al., 2010). In drip irrigation system water is supplied frequently, often daily to maintain favorable soil moisture conditions and prevent the plants from moisture-stress and also to ensure proper use of water resources (Galande and Agrawal, 2013).

Many farmers in developed countries such as USA and Australia have already adopted these modern techniques (Shirgure, 2012). Kumar et al. (2008) stated that the real water saving would be more for row crops such as fruit orchards, cotton, fennel, castor, and many vegetables. He further added that under traditional irrigation system a large area between the plants row is directly exposed to solar radiation and wind, and as a result the non-beneficial evaporation would be a major component of the total water depletion. Kanber et al. (2007) have pointed out that enhancement in WUE depends on productivity gains depicted by consistent increase in output per unit input and the irrigation technique. Improved WUE in agriculture is important for water conservation and to obtain higher yields. Modern irrigation technologies such as sprinkler and micro irrigation are efficient and have the potential to substantially improve yield. Furthermore, among pressurized irrigation systems, drip system ensures more irrigation water saving compared with full cover and strip cover sprinklers (Kadyampakeni et al., 2014). According to the best of our knowledge, limited reports are available regarding the impact of pressurized irrigation systems for fruit plants in Pakistan. This study was conducted to assess the effect of pressurized irrigation systems on the fruit yield and WUE of Kinnow mandarin under agroclimatic conditions of Sargodha, Pakistan.

\section{MATERIALS AND METHODS}

Experimental area and design: The study was conducted at CRI, Sargodha, Punjab, Pakistan $\left(32^{\circ} 4^{\prime}\right.$ ' $\mathrm{N}$ and $72^{\circ} 40^{\prime}$ ' E) on 25 years old Kinnow mandarin plants. The plants were grafted onto rough lemon rootstock cultivated on silt clay loam soil (soil characteristics of the experimental area are provided in Table 1). The experiment duration was 4 years from 2011-2015. A 0.5 ha Kinnow block with planting geometry of $6.1 \mathrm{~m} \times 6.1$ $\mathrm{m}$ square system, previously under flood irrigation system was equally divided into three blocks. Four different irrigation systems: drip irrigation (DI), full cover sprinkler (FCS), and strip cover sprinkler (SCS) irrigation systems were established in each block separately and for traditional flood irrigation (TFI) system a separate block of 0.5 ha was selected as a control. Experiment was laid out according to randomized complete block design (RCBD). Three plants were selected as a treatment unit and each treatment was replicated four times. One complete row between the experimental plants was kept as buffer line to eliminate any kind of error caused by seepage effect. Each block of every irrigation system received equal amount of nutrients including $1000 \mathrm{~g}$ nitrogen, $500 \mathrm{~g}$ phosphorus and $500 \mathrm{~g}$ potash per plant, annually. All phosphorus and potash fertilizers were applied in January whereas nitrogen (except drip irrigation system) was applied in three equal splits (last week of February, last week of May and August. In drip irrigation system nitrogenous fertilizer (Urea) was applied as fertigation. Through fertigation, 20\% N was applied before flowering (February to March), 60\% $\mathrm{N}$ was applied from fruit setting to cell division and cell development stage (April to June), and remaining $20 \% \mathrm{~N}$ was applied during late summer to colour break stage (July to mid October).

Physiochemical properties of the soil: The soil was silt clay loam. EC and $\mathrm{pH}$ indicated that it was a normal but calcareous in nature. The phosphorus and potassium contents were found in optimum range but organic matter percentage was in deficient range (Table 1).

Irrigation schedule: Irrigation schedule for different irrigation systems such as DI, FCS and SCS was developed on the basis of soil pit examination at experimental site and evapotranspiration source from University of Agriculture Faisalabad, Pakistan.

Installation of tensiometers and measurement of water discharge: Tensiometers were installed in each block at $30 \mathrm{~cm}, 60 \mathrm{~cm}$, and $90 \mathrm{~cm}$ soil depth to monitor the moisture level in the soil. The irrigation was applied when tensiometer reading reached above 40 centibars (an average reading of tensiometers which were installed at $30 \mathrm{~cm}$ and $60 \mathrm{~cm}$ depth). A flume meter was used to measure the total quantity of water applied under flood irrigation system. In DI system, two drip lines were installed under the tree canopy along each tree row planted in $6.1 \mathrm{~m} \times 6.1 \mathrm{~m}$ distance. Each drip line had 15 pressure compensator drippers with water discharge of $1.66 \mathrm{mmh}^{-1}$, and 30 drippers were used for each tree, therefore each tree received irrigation water of $49.8 \mathrm{mmh}^{-}$ ${ }^{1}$. In FCS, one sprinkler with discharge of $5.5 \mathrm{mmh}^{-1}$ was 
installed within each tree row whereas in SCS, three sprinklers were installed under each tree's canopy with discharge of $3.5 \mathrm{mmh}^{-1}$, and therefore, received irrigation water of $10.5 \mathrm{mmh}^{-1}$ tree ${ }^{-1}$. The total operational hours per season were recorded and total irrigation water applied to each pressurized system was calculated as:

Total irrigation water applied to each tree

$$
\begin{aligned}
& =\text { Total operational hours } \\
& \times \text { Discharge rate }(m m-1)
\end{aligned}
$$

Water Use Efficiency $\left(\mathrm{kg} \mathrm{m}^{-3}\right)$ : WUE was calculated using the following formula:

$$
\begin{aligned}
W U E=\{\text { Total } & \text { yield }(t \text { ha } \\
& -1) / \text { Total water used }(\mathrm{mm})\} \\
& \times 100
\end{aligned}
$$

Measurement of yield and different fruit characteristics: At fruit maturity, total fruit yield (kgtree${ }^{1}$ ) was determined by harvesting all fruits on a tree. Fruit size (diameter) of one hundred fruits per tree at random was measured with digital vernier caliper at maturity stage. Ten fruits tree ${ }^{-1}$ were collected for measuring the average fruit weight $\left(\right.$ gfruit $\left.^{-1}\right)$ and further used for physicochemical analysis of the fruit. Rotary squeezer was used to extract the juice from the fruits. The juice was filtered using $0.8 \mathrm{~mm}$ sieve. The weight of juice was measured using an electric balance and juice percentage was calculated according to the following formula (Ahmed et al., 2007):

Juice $\%=$ Juice weight $(g) /$ Fruit weight $\times 100$ The rag percentage was determined using the following formula:

$$
\begin{aligned}
& \operatorname{Rag}(\%)=\text { Fruit weight } \\
& \qquad-\frac{\text { juice weight }+ \text { peel weight }}{\text { fruit weight }} \\
& \quad \times 100 \quad
\end{aligned}
$$

Total soluble solids (TSS) were determined using a refractometer. The acidity was determined by titration with $0.1 \mathrm{~N} \mathrm{NaOH}$ using a known volume of representative sample of the fruit juice. Phenolphthalein was used as an indicator to check the persistent pink colour (Lacey et al., 2009; Nawaz et al., 2008).

Statistical analysis: The data were analyzed using Statistix software version 8.1 (Analytical Software, Miller Landing Rd, Florida, USA). Four years data were pooled and then analysis of variance (ANOVA) was performed (Steel et al., 1997). Treatment means were compared using Fishers least significant difference test at $P \leq 0.05$.

\section{RESULTS}

Yield and physicochemical properties of Kinnow fruit: Different irrigation systems significantly affected the fruit yield and physicochemical characteristics of Kinnow. Number of fruitstree ${ }^{-1}(1288)$ and fruit yield $\left(181 \mathrm{kgtree}^{-1}\right)$ were significantly $(P \leq 0.05)$ increased by using DI system followed by FCS (151 kg tree $\left.{ }^{-1}\right)$. Different irrigation systems had no effect on individual fruit weight.

Fruit diameter was significantly improved for the fruits obtained from the plants irrigated with TFI system; however, the diameter of the fruits obtained from plants irrigated by all other irrigation systems was not significantly different (Table 4).

A gradual increasing trend was observed on the yield during four years of this study in DI, FCS and SCS irrigation systems. In TFI system, fruit yield during different years of the study did not increase significantly. An average higher yield (43.88 $\mathrm{t} \mathrm{ha}^{-1}$ ) was found in drip irrigation system $(40.46 \%$ higher) compared with TFI system (26.12 $\left.\mathrm{t} \mathrm{ha}^{-1}\right)$. Fruit yield was $28.45 \%$ and $27.19 \%$ higher in FCS and SCS irrigation systems, respectively compared with TFI system (Table 5).

Juice percentage was significantly $(P \leq 0.05)$ affected because of different irrigation systems (Table 6). FCS and DI system produced significantly higher fruit juice percentage of $48.70 \%$ and $47.68 \%$, respectively whereas lower juice percentage of $46.41 \%$ and $47.01 \%$ was observed for SCS irrigation system and TFI system, respectively.

Total water consumption and irrigation water saving in different irrigation systems: During the crop season from 2011-15 the average water saving in drip irrigation system was $55 \%$ and $30 \%$ in strip cover sprinkler irrigation system compared with flood irrigation system. An economical water consumption was observed for drip irrigation system (195.92 mm year ${ }^{-1}$ and total water 904.37 mmyear $^{-1}$ ), followed by strip cover sprinkler where irrigation water usage and total water consumption was 300.89 mmyear $^{-1}$ and 1009.34 mmyear $^{-1}$, respectively. Full cover sprinkler and flood irrigation systems used comparatively high delta of water compared with drip irrigation, strip cover sprinkler irrigation system (Table 7).

Water Use Efficiency (WUE) of different irrigation systems: Average WUE was higher $\left(4.85 \mathrm{kgm}^{-3}\right)$ for DI system followed by SCS irrigation system. The better WUE of $10.65 \mathrm{~kg} \mathrm{~m}^{-3}, 9.99 \mathrm{~kg} \mathrm{~m}^{-3}$ and $5.83 \mathrm{~kg} \mathrm{~m}^{-3}$ was observed for DI, SCS and FCS, respectively during 2013 14 (Fig. 1). 
Table 1. Fertility status of experimental area (pretreatment).

\begin{tabular}{|c|c|c|c|c|c|c|}
\hline Soil depth (cm) & pH & $E C\left(d S m^{-1}\right)$ & $\begin{array}{l}\text { OM } \\
(\%)\end{array}$ & $\begin{array}{c}\text { Av. P } \\
\text { (ppm) }\end{array}$ & $\begin{array}{l}\text { Av. K } \\
\text { (ppm) }\end{array}$ & Texture \\
\hline $0-15$ & 7.9 & 0.15 & 0.90 & 20.20 & 168 & Silt clay loam \\
\hline $15-30$ & 8.0 & 0.11 & 0.65 & 14.16 & 75 & \\
\hline $30-60$ & 8.0 & 0.09 & & & & \\
\hline $60-90$ & 7.9 & 0.10 & & & & \\
\hline $90-120$ & 8.0 & 0.09 & & & & \\
\hline $120-150$ & 7.8 & 0.08 & & & & \\
\hline
\end{tabular}

EC: electrical conductivity, OM: organic matter, Av: average

Table 2. Evapotranspiration, crop coefficient, monthly, and daily water requirement for large citrus trees - $70 \%$ ground cover.

\begin{tabular}{lcccc}
\hline Month & $\begin{array}{c}\text { Evapotranspiration (mm) } \\
\text { per day }\end{array}$ & $\begin{array}{c}\text { Crop } \\
\text { Coefficient }\end{array}$ & $\begin{array}{c}\text { Monthly water requirements } \\
\text { (full production) (mm) }\end{array}$ & $\begin{array}{c}\text { Daily water requirement } \\
\text { (full production) (mm) }\end{array}$ \\
\hline January & 1.4 & 0.7 & 30 & 1 \\
February & 2.2 & 0.7 & 48 & 1.5 \\
March & 3.5 & 0.7 & 76 & 2.5 \\
April & 4.8 & 0.7 & 101 & 3.4 \\
May & 6.2 & 0.7 & 130 & 4.3 \\
June & 6.5 & 0.7 & 141 & 4.6 \\
July & 5.4 & 0.7 & 117 & 3.8 \\
August & 4.9 & 0.7 & 106 & 3.4 \\
September & 4.7 & 0.7 & 102 & 3.3 \\
October & 3.3 & 0.7 & 69 & 2.3 \\
November & 1.9 & 0.7 & 41 & 1.3 \\
December & 1.5 & 0.7 & 32 & 1.1 \\
\hline
\end{tabular}

Total Crop Water Use: $994 \mathrm{~mm}$ or $9.9 \mathrm{ML} / \mathrm{ha}$. Soil deficit is assumed to be $50 \mathrm{~mm}$ based on soil pit.

Table 3. Approximate irrigation requirement for drip, full cover sprinkler (FCS) and strip cover sprinkler (SCS) irrigation systems.

\begin{tabular}{lccc}
\hline Month & $\begin{array}{c}\text { Approximate irrigation } \\
\text { requirement for drip }\end{array}$ & $\begin{array}{c}\text { Approximate irrigation } \\
\text { requirement for FCS }\end{array}$ & $\begin{array}{c}\text { Approximate irrigation } \\
\text { requirement for SCS }\end{array}$ \\
\hline January & $10 \mathrm{~h} / 15$ days & $10 \mathrm{~h} / 1$ per month & $8 \mathrm{~h} / 1 \mathrm{per}$ month \\
February & $10 \mathrm{~h} / 10$ days & $10 \mathrm{~h} / 1$ per month & $8 \mathrm{~h} / 15 \mathrm{days}$ \\
March & $10 \mathrm{~h} / 6$ days & $10 \mathrm{~h} / 15$ days & $8 \mathrm{~h} / 10 \mathrm{days}$ \\
April & $10 \mathrm{~h} / 4$ days & $10 \mathrm{~h} / 15$ days & $8 \mathrm{~h} / 7 \mathrm{days}$ \\
May & $10 \mathrm{~h} / 3$ days & $10 \mathrm{~h} / 10$ days & $8 \mathrm{~h} / 5 \mathrm{days}$ \\
June & $10 \mathrm{~h} / 2$ days & $10 \mathrm{~h} / 10$ days & $8 \mathrm{~h} / 5 \mathrm{days}$ \\
July & $10 \mathrm{~h} / 4$ days & $10 \mathrm{~h} / 12$ days & $8 \mathrm{~h} / 6 \mathrm{days}$ \\
August & $10 \mathrm{~h} / 4$ days & $10 \mathrm{~h} / 15$ days & $8 \mathrm{~h} / 7 \mathrm{days}$ \\
September & $10 \mathrm{~h} / 4$ days & $10 \mathrm{~h} / 15$ days & $8 \mathrm{~h} / 7 \mathrm{days}$ \\
October & $10 \mathrm{~h} / 6$ days & $10 \mathrm{~h} / 15$ days & $8 \mathrm{~h} / 10 \mathrm{days}$ \\
November & $10 \mathrm{~h} / 11$ days & $10 \mathrm{~h} / 1$ per month & $8 \mathrm{~h} / 15 \mathrm{days}$ \\
December & $10 \mathrm{~h} / 13$ days & $10 \mathrm{~h} / 1$ per month & $8 \mathrm{~h} / 1 \mathrm{per}$ month \\
\hline
\end{tabular}

It is assumed that the drip system applies water to approximately $1 / 3$ of the total area. Therefore the root zone deficit becomes $50 / 3=$ 16.6 (say $15 \mathrm{~mm}$ ). The dripper application rate is $1.66 \mathrm{~mm} / \mathrm{h}$. Therefore the largest irrigation volume that should be applied is $15 \mathrm{~mm}$ or $15 \mathrm{~mm} / 1.66=9$ (say 10 hours). In FCS the sprinkler application rate is $5.55 \mathrm{~mm} / \mathrm{h}$. Therefore the largest irrigation volume that should be applied is $50 \mathrm{~mm}$ or $50 \mathrm{~mm} / 5.55=9$ (say 10) hours. It is assumed that the strip sprinkler system applies water to approximately $1 / 2$ of the total area. Root zone deficit becomes $50 / 2=25 \mathrm{~mm}$. In SCS the sprinkler application rate is $3.5 \mathrm{~mm} / \mathrm{h}$. Therefore the largest irrigation volume that should be applied is $25 \mathrm{~mm}$ or $25 \mathrm{~mm} / 3.5=7$ (say 8) hours. Three times per year apply 12 hours to leach salts from the root zone. 
Table 4. Effect of different irrigation systems on the fruit yield and yield attributes.

\begin{tabular}{lcccc}
\hline Irrigation systems & No. fruit tree & Fruit yield $\left.^{-1} \mathbf{K g ~ t r e ~}^{-\mathbf{1}}\right)$ & Fruit weight $_{(g)}$ & Fruit diameter (mm) \\
\hline Drip irrigation & $1228 \mathrm{~A}$ & $181.13 \mathrm{~A}$ & $152.14 \mathrm{~A}$ & $68.78 \mathrm{BC}$ \\
Full cover sprinkler & $1029 \mathrm{~B}$ & $151.34 \mathrm{~B}$ & $149.15 \mathrm{~A}$ & $70.12 \mathrm{~B}$ \\
Strip cover sprinkler & $1045 \mathrm{~B}$ & $147.92 \mathrm{~B}$ & $155.18 \mathrm{~A}$ & $67.58 \mathrm{C}$ \\
Traditional Flood irrigation & $687 \mathrm{C}$ & $104.55 \mathrm{C}$ & $152.34 \mathrm{~A}$ & $73.16 \mathrm{~A}$ \\
$\mathrm{CV}^{\mathrm{a}}$ & 151.15 & 20.32 & 6.4606 & 2.12 \\
\hline
\end{tabular}

${ }^{\mathrm{a} C}$ Coefficient of variation. Means followed by the similar letters in the column do not differ at $P \leq 0.05$.

Table 5. Impact of different irrigation systems on yield $\left(\mathrm{t} \mathrm{ha}^{-1}\right)$ of Kinnow.

\begin{tabular}{lccccc}
\hline Irrigation systems & $\mathbf{2 0 1 1 - 1 2}$ & $\mathbf{2 0 1 2 - 1 3}$ & $\mathbf{2 0 1 3 - 1 4}$ & $\mathbf{2 0 1 4 - 1 5}$ & Average \\
\hline Drip irrigation (DI) & 28.75 & 32.37 & 49.66 & 64.74 & 43.88 \\
Full cover sprinkler (FCS) irrigation & 27.26 & 24.72 & 35.69 & 58.38 & 36.51 \\
Strip cover sprinkler (SCS) irrigation & 32.71 & 22.28 & 40.11 & 48.4 & 35.88 \\
Traditional flood irrigation (TFI) system & 30.02 & 23.72 & 23.65 & 27.11 & 26.12 \\
\hline
\end{tabular}

Table 6. Effect of different irrigation systems on the physicochemical properties of the Kinnow fruit.

\begin{tabular}{lcccc}
\hline Irrigation systems & Juice (\%) & Rag (\%) & Peel (\%) & TSS/Acidity ratio \\
\hline Drip irrigation & $47.68 \mathrm{AB}$ & $20.61 \mathrm{~A}$ & $31.70 \mathrm{~A}$ & $15.57 \mathrm{~A}$ \\
Full cover sprinkler & $48.70 \mathrm{~A}$ & $19.24 \mathrm{~A}$ & $32.07 \mathrm{~A}$ & $15.34 \mathrm{~A}$ \\
Strip cover sprinkler & $46.41 \mathrm{~B}$ & $20.90 \mathrm{~A}$ & $32.68 \mathrm{~A}$ & $15.90 \mathrm{~A}$ \\
Traditional flood irrigation & $47.01 \mathrm{~B}$ & $21.26 \mathrm{~A}$ & $31.75 \mathrm{~A}$ & $16.02 \mathrm{~A}$ \\
$\mathrm{CV}^{\mathrm{a}}$ & 1.62 & 1.99 & 1.4 & 0.95 \\
\hline${ }^{\mathrm{a} C o f f i c i e n t ~}$ f variation.
\end{tabular}

${ }^{a}$ Coefficient of variation. Means followed by the similar letters in the column do not differ at $P \leq 0.05$.

Table 7. Total water consumption by different irrigation systems.

\begin{tabular}{|c|c|c|c|c|c|c|c|c|c|}
\hline \multirow[b]{2}{*}{ Year } & \multicolumn{2}{|c|}{ Drip irrigation (DI) } & \multicolumn{2}{|c|}{$\begin{array}{c}\text { Full cover sprinkler } \\
\text { (FCS) }\end{array}$} & \multicolumn{2}{|c|}{$\begin{array}{c}\text { Strip cover } \\
\text { sprinkler (SCS) }\end{array}$} & \multicolumn{2}{|c|}{$\begin{array}{c}\text { Traditional flood } \\
\text { irrigation(TFI) }\end{array}$} & \multirow[b]{2}{*}{ Rainfall } \\
\hline & Irrigation & Total W & Irrigation & $\begin{array}{c}\text { Total } \\
\text { W }\end{array}$ & Irrigation & $\begin{array}{c}\text { Total } \\
\text { W }\end{array}$ & Irrigation & $\begin{array}{c}\text { Total } \\
\text { W }\end{array}$ & \\
\hline & \multicolumn{9}{|c|}{$\mathrm{mm}$} \\
\hline 2011-12 & 188.66 & 411.98 & 515.99 & 739.31 & 354.74 & 578.06 & 432.68 & 656.00 & 223.32 \\
\hline $2012-13$ & 338.62 & 755.62 & 951.36 & 1368.36 & 567.59 & 984.59 & 588.82 & 1005.82 & 417 \\
\hline 2013-14 & 146.73 & 466.23 & 292.93 & 612.43 & 165.12 & 484.62 & 473.67 & 793.17 & 319.5 \\
\hline $2014-15$ & 109.65 & 1983.65 & 225.75 & 2099.75 & 116.10 & 1990.10 & 238.43 & 2112.43 & 1874 \\
\hline Average & 195.92 & 904.37 & 496.51 & 1204.96 & 300.89 & 1009.34 & 433.40 & 1141.86 & 708.45 \\
\hline
\end{tabular}

Total W $(\mathrm{mm})=$ Irrigation + Rainfall

Table 8. Combined ANOVA

\begin{tabular}{|c|c|c|c|c|c|c|c|}
\hline \multirow[t]{2}{*}{ SOV } & \multicolumn{7}{|c|}{ MSE } \\
\hline & Number of fruit tree ${ }^{-1}$ & Fruit yield & Fruit dia. & Fruit weight & Juice $\%$ & Peel \% & $\operatorname{Rag} \%$ \\
\hline Treatment & $812691^{* *}$ & $15916.6^{* *}$ & $92.25^{* *}$ & $97.04 \mathrm{NS}$ & $15.4329^{*}$ & $3.287^{\mathrm{NS}}$ & $12.573^{\mathrm{NS}}$ \\
\hline Year & $2190685^{* *}$ & $29941.3^{* *}$ & $350.407^{* *}$ & $1539.65^{*}$ & $36.8764^{*}$ & $282.779^{* *}$ & $173.761^{* *}$ \\
\hline Treat*Year & $261837^{* *}$ & $4766.4^{* *}$ & $215.564^{* *}$ & $201.55^{*}$ & $5.1074^{\mathrm{NS}}$ & $3.994^{\mathrm{NS}}$ & $6.846^{\mathrm{NS}}$ \\
\hline
\end{tabular}

${ }^{* *}$ Highly significant at $P \leq 0.005$

*Significant at $P \leq 0.05$

NS: Non-significant 


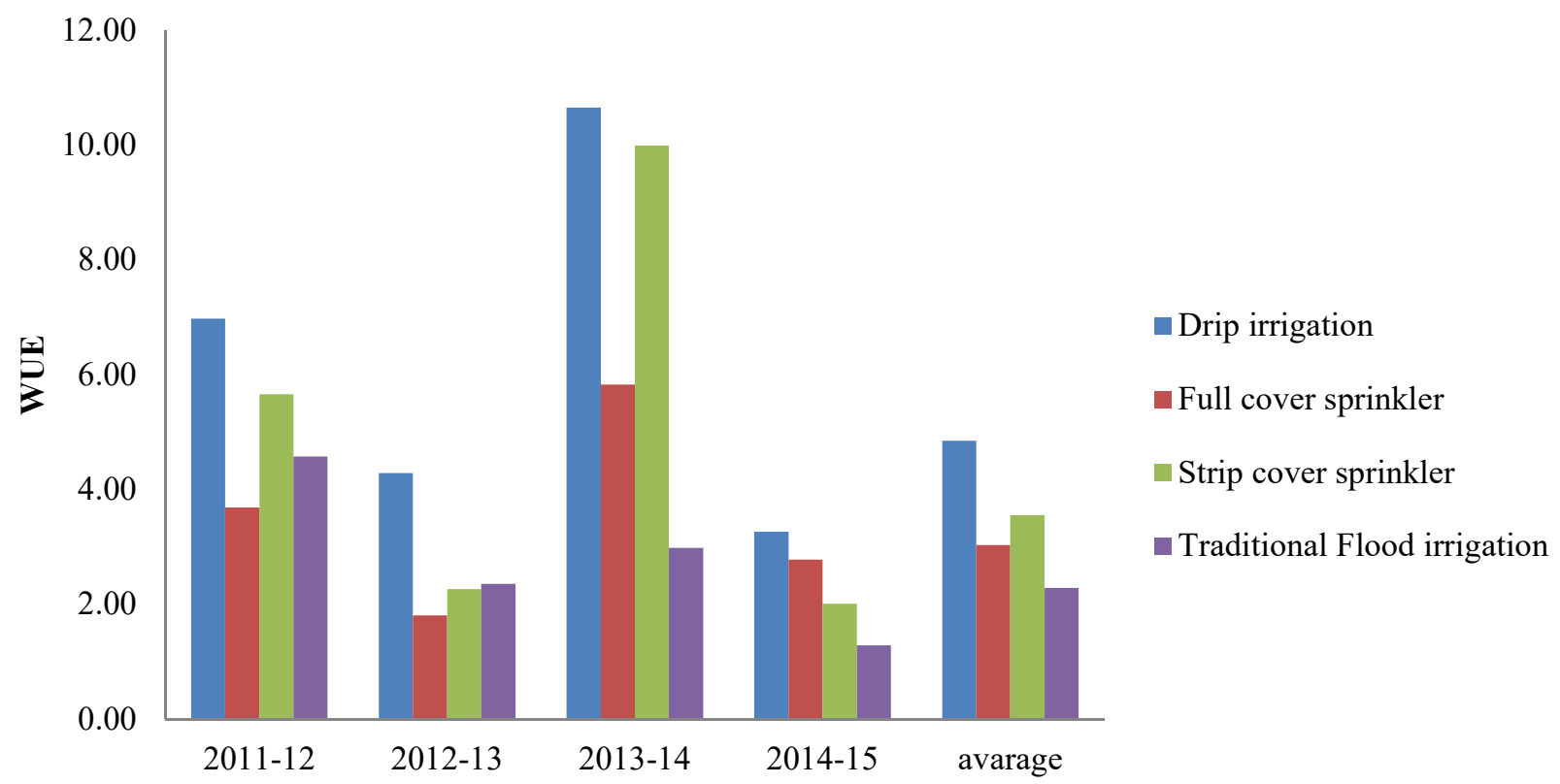

Figure 1. WUE $\left(\mathrm{kg} \mathrm{m}^{-3}\right)$ of different irrigation systems. A height of the column represents the intensity of WUE.

\section{DISCUSSION}

Effect of irrigation systems on the fruit yield and physicochemical properties of Kinnow fruit: Pressurized irrigation systems proved their advantage over flood irrigation system in terms of yield. Among pressurized irrigation systems, the drip and strip cover sprinkler performed better for producing higher fruit yield. Performance of drip irrigation system was excellent in terms of yield because in drip system a frequent irrigation supply was maintained in the active root zone of the tree and therefore losses of essential nutrients because of leaching were reduced. Another factor of increased fruit yield in drip irrigation system is application of the nitrogen fertilizer through fertigation method (Shirgure, 2012). In pressurized irrigation systems (DI, FCS and SCS irrigation system), yield was gradually increased from $1^{\text {st }}$ year (2011) of experiment to the final year (2015) of the study. This increase in yield can be attributed to maintenance of optimum moisture level in the soil, suppression of weed growth and less disturbance of the roots (Panigrahi et al., 2012) that promoted plant growth. Higher juice percentage was obtained from full cover sprinkler and drip irrigation system whereas this was lower in strip and flood irrigation systems. This might be due to larger sized fruit with higher peel and rage percentage, therefore less juice percentage was produced (Sandhu, 1991). Holzapfel et al. (2004) obtained higher yields in blueberry with drip irrigation system compared with sprinkler systems with similar amounts of applied water. In our study, fruit weight remained similar with all irrigation systems although fruits with larger diameter (fruit size) were produced in flood irrigation system compared with other irrigation system utilized in this study. This increase in fruit size might be attributed to larger differences in fruit yield as compared to pressurized irrigation systems (Guardiola and García-Luis, 2000; Smith and Samach, 2013). Katuuramu et al. (2011) and Meland (2009) also found similar results for apple and concluded that size and weight of apple fruit were affected by the crop load.

Total water consumption in different irrigation systems and irrigation water saving: According to the findings of our study, 55\% water saving is achieved using drip irrigation system and 35\% water saving is achieved using strip cover sprinkler irrigation system compared with TF. Sprinkler irrigation systems seems less suitable over drip irrigation system because under hot and dry climatic conditions of Pakistan temperature reaches to a maximum of $48-50{ }^{\circ} \mathrm{C}$, thus evaporation losses are increased and a large amount of water cannot be available to the plants (Abbas and Fares, 2009). Furthermore, maintenance cost of sprinkler irrigation system is also higher compared with drip irrigation system. According to another report, water saving is generally higher for drip irrigation systems compared with sprinkler irrigation systems (Kumar and van Dam, 2013). With drip irrigation, water could be directly applied to the plants, preventing non-beneficial evaporation. This will not be possible with sprinklers because sprinklers wet the entire field area instead of the plant root zone (Viswanathan et al., 2016). Similarly, Fallahi et al. (2010) observed that application of water using drip irrigation system, calculated based on full ETc rate and adjusted for groundcover, results in major water saving and improves the yield and fruit quality of apples. According to Hijazi 
et al. (2014) application of water by drip irrigation to olive trees also resulted in $34.40 \%$ water saving and improved the fruit yield by up to $19.20 \%$ compared with surface irrigation system using soil rings.

In drip irrigation system, water is applied directly to the root zone of area drop by drop in small amount thus subjected to less evaporation or deep percolation below the active root zone, whereas sprinkler system spreads water directly into the air thus water losses are increased. In this study, drip irrigation system consumed minimum amount of irrigation water (195.92 $\mathrm{mm}$ ) followed by strip cover sprinkler $(300.89 \mathrm{~mm})$ compared with flood irrigation system (433.40 $\mathrm{mm}$ ) (Table VII). Water consumption under flood irrigation system was higher because in flood irrigation a huge amount of water had been applied to irrigate the entire field without targeting the root zone of trees. Resultantly, a lot of water is lost because of evaporation and deep percolation. Rainfall is the major contributing factor that affects the irrigation water requirements. There is greater difference in irrigation water consumption and rainfall contribution. According to data, rainfall ranged from a minimum of $223 \mathrm{~mm}$ during 2010-2011 to maximum of $1874 \mathrm{~mm}$ during 2014-2015. The highest rainfall received during 2014-2015 could not be considered beneficial for orchards because most of the rainfall occurred during two months (July to August, 2014-2015).

Water Use Efficiency (WUE) of different irrigation systems: WUE depends upon output [yield $\left.\left(\mathrm{t} \mathrm{ha}^{-1}\right)\right]$ and input [total water $(\mathrm{mm})$ ] consumed. In this study, WUE was higher for drip irrigation system $\left(4.85 \mathrm{~kg} \mathrm{~m}^{-3}\right)$ followed by strip cover sprinkler irrigation system $(3.55$ $\mathrm{kg} \mathrm{m}{ }^{-3}$ ). The improved WUE for drip irrigation system can be attributed to low potential evaporative losses compared with sprinkler irrigation system. Similar results were also reported by Maisiri et al. (2005), they observed that drip irrigation uses only $35 \%$ of the water compared with surface irrigation system, providing higher IWUE (irrigation water use efficiency). Similarly, Yin et al. (2011) reported that drip irrigation system consumed only $21 \%$ to $29 \%$ of irrigation water compared with micro sprinkler irrigation system, and WUE was improved by $167 \%$ to $234 \%$ with drip irrigation system compared with micro sprinkler irrigation system. Fruit yield and fruit quality including firmness, color, and size did not differ regardless of irrigation system. According to another report, surface and drip irrigation systems ensures $28 \%$ to $35 \%$ water saving compared with improved graded furrows, and increase water productivity from $0.43 \mathrm{~kg} \mathrm{~m}^{-3}$ to $0.61 \mathrm{~kg} \mathrm{~m}^{-3}$ (Darouich et al., 2014).

Conclusion: This study shows that drip irrigation system improves the fruit yield of Kinnow and ensures water saving. Moreover, higher WUE was also achieved by using drip irrigation system compared with traditional flood irrigation system. Consumptive use of water was the minimum in drip irrigation system followed by strip cover sprinkler irrigation system. Taken together, drip irrigation is recommended followed by strip cover sprinkler among the different pressurized irrigation methods on the basis of good yield and higher WUE of Kinnow orchard. Thus, citrus growers of Sargodha (Punjab, Pakistan) area can adopt drip irrigation system to improve the Kinnow yield and WUE.

Acknowledgements: This study was supported by Agriculture Sector Linkage Program (ASLP), Citrus Project under Australian Aid Program. The authors are thankful to Prof. José Eduardo Serrão, Department of General Biology, Federal University of Viçosa, Brazil for improving the language of this manuscript.

Conflict of interest: All the authors declare no conflict of interest.

\section{REFERENCES}

Abbas, F., and A. Fares (2009). Best management practices in citrus production. Tree Forestry Sci. Biotechnol. 3:1-11.

Ahmed, W., M.A. Nawaz, M.A. Iqbal, and M. Khan (2007). Effect of different rootstocks on plant nutrient status and yield in Kinnow mandarin (Citrus reticulata Blanco). Pakistan J. Bot. 39:1779-1786.

AMIS. (2017). Agriculture Marketing Information Service, Agriculture Department, Government ofPakistan.http://www.amis.pk/Crop\%20Data/2 017/Area/Citrus.html.

Bryla, D.R., E. Dickson, R. Shenk, R.S. Johnson, C. H. Crisosto, and T.J. Trout (2005). Influence of irrigation method and scheduling on patterns of soil and tree water status and its relation to yield and fruit quality in peach. Hort. Sci. 40:21182124.

Carr, M. K. V. (2012). The water relations and irrigation requirements of citrus (Citrus spp.): a review. Exp. Agri. 48:347-377.

Darouich, H.M., C.M. Pedras, J.M. Gonçalves, and L.S. Pereira (2014). Drip vs. surface irrigation: A comparison focusing on water saving and economic returns using multicriteria analysis applied to cotton. Biosystems Engineering. 122:74-90.

Fallahi, E., D. Neilsen, G.H. Neilsen, B. Fallahi, and B. Shafii (2010). Efficient irrigation for optimum fruit quality and yield in apples. Hort. Sci. 45:1616-1625.

FAO, 2017. FAO database. Food and Agriculture Organization, Rome. http://fenixservices.fao. org/faostat/static/bulkdownloads/ Food Balance Sheets_E_Asia.zip (accessed on 30 October, 2019) 
Fateh, F.S., T. Mukhtar, M.R. Kazmi, N.A. Abbassi, and A.M. Arif (2017). Prevalence of citrus decline in district sargodha. Pakistan J. Agri. Sci. 54:9-13.

Galande, M.S., and D.G. Agrawal (2013). Embedded Controlled Drip Irrigation System. Int. J. of Emerging Trend. Technol. Computer Sci. 2: 3741.

Guardiola, J., and A. García-Luis (2000). Increasing fruit size in Citrus. Thinning and stimulation of fruit growth. Plant Growth Regulation. 31:121-132.

Hijazi, A., M. Doghoze, N. Jouni, V. Nangia, M. Karrou, and T. Oweis (2014). Water Requirement and Water-use Efficiency for Olive Trees under Different Irrigation Systems. Proceedings of the 7th International Conference on Water Resources in the Mediterranean Basin.Marrakech, Morocco. 1-5.

Holzapfel, E., R. Hepp, and M. Mariño (2004). Effect of irrigation on fruit production in blueberry. Agricultural Water Management. 67:173-184.

Kadyampakeni, D.M., K.T. Morgan, A.W. Schumann, P. Nkedi-Kizza, and T.A. Obreza (2014). Water use in drip-and microsprinkler-irrigated citrus trees. Soil Sci. Soc. America J. 78:1351-1361.

Kanber, R., M. Unlu, E. Cakmak, and M. Tuzun (2007). Water use efficiency in Turkey. Proceedings of 4th WASAMED (Water Saving in Mediterranean agriculture) Workshop. 178-189.

Katuuramu, D., G.R. Nonnecke, and P.A. Domoto (2011). Influence of Crop Load on Tree Growth, Yield, and Fruit Quality of Scab Resistant Apples at Harvest. Lowa State Res. Farm Progr. Rep. RFR-A1135: 55-56.

Khalid, S. (2013). Fruit quality and storability of Kinnow mandarin (Citrus reticulata Blanco) in relation to tree age. Doctoral dissertation. Uni. Agri., Faisalabad, Pakistan.

Khalid, S., A.U. Malik, B.A. Saleem, A.S. Khan, M.S. Khalid, and M. Amin (2012). Tree age and canopy position affect rind quality, fruit quality and rind nutrient content of 'Kinnow'mandarin (Citrus nobilis Lour× Citrus deliciosa Tenora). Sci Hort. 135:137-144.

Kumar, M.D. (2016). Water Saving and Yield Enhancing Micro Irrigation Technologies in India: Theory and Practice. In Micro Irrigation Systems in India. Springer. 13-36.

Kumar, M.D., H. Turral, B. Sharma, U. Amarasinghe, and O. Singh (2008). Water saving and yield enhancing micro irrigation technologies in India: When and where can they become best bet technologies. Managing water in the face of growing scarcity, inequity and declining returns: Exploring fresh approaches. 1:1-36.

Kumar, M.D., and J.C. van Dam (2013). Drivers of change in agricultural water productivity and its improvement at basin scale in developing economies. Water International. 38:312-325.

Lacey, K., N. Hancock, and H. Ramsey (2009). Measuring internal maturity of citrus. Department of Primary Industries and Regional Development. Government of Western Australia. Farmnote no. 354:1-4.

Maisiri, N., A. Senzanje, J. Rockstrom, and S. Twomlow (2005). On farm evaluation of the effect of low cost drip irrigation on water and crop productivity compared to conventional surface irrigation system. Physic. Chemist. Earth, parts A/B/C. 30:783-791.

Meland, M. (2009). Effects of different crop loads and thinning times on yield, fruit quality, and return bloom in Malus $\times$ domestica Borkh. 'Elstar'. J. Hort. Sci. Biotechnol. 84:117-121.

Mirjat, M., M. Jiskani, A. Siyal, and M. Mirjat (2011). Mango production and fruit quality under properly managed drip irrigation system. Pakistan J. Agri., Agril. Engg., Vet. Sci. 27:112.

Morgan, K.T., L. Zotarelli, and M.D. Dukes (2010). Use of irrigation technologies for citrus trees in Florida. Hort. Technol. 20:74-81.

Nawaz, M.A., W. Ahmad, S. Ahmad, and M.M. Khan (2008). Role of growth regulators on preharvest fruit drop, yield and quality in kinnow mandarin. Pakistan J. Bot. 40:1971-1981.

Panigrahi, P., A. Srivastava, and A. Huchche (2012). Effects of drip irrigation regimes and basin irrigation on Nagpur mandarin agronomical and physiological performance. Agri. Water Management. 104:79-88.

Sandhu, S. (1991). Postharvest handling techniques for cv. Kinnow mandarin. Front. Tropic. Fruit Res. 321:747-755.

Rockström, J., M. Lannerstad, and M. Falkenmar (2007). Assessing the water challenge of a new green revolution in developing countries. Proc. Natl. Acad. Sci. 104: 6253-6260.

Savita, G.S.V., and A. Nagpal (2012). Citrus diseases caused by Phytophthora species. GERF Bull. Biosci. 3:18-27.

Shireen, F., M. J. Jaskani, M. A. Nawaz, and F. Hayat (2018). Exogenous application of naphthalene acetic acid improves fruit size and quality of Kinnow mandarin (Citrus reticulata) through regulating fruit load. J. Ani. Plant Sci. 28: 10801084.

Shirgure, P., A. Srivastava, and S. Singh (2000). Water Management in Citrus-A Review. Agri. Rev. Agri. Res. Comm. Centre India. 21:223-230.

Shirgure, P.S. (2012). Micro-irrigation systems, automation and fertigation in citrus. Scient. J. Rev. 1:156-169. 
Singh, S., and N. Sharma (2012). Research paper on drip irrigation management using wireless sensors. Int. J. Computer Networks Wireless Comm. 2:461-464.

Smith, H.M., and A. Samach (2013). Constraints to obtaining consistent annual yields in perennial tree crops. I: Heavy fruit load dominates over vegetative growth. Plant Sci. 207:158-167.

Steel, R. G. D., J. H. Torrieand D. A. Dickey (1997). Principals and Procedures of Statistics: A Biomaterial Approach. $3^{\text {rd }}$ Edition. Megraw Hill; New York. 107-109 p.
TDAP. (2019). Trade Development Authority of Pakistan, Agriculture Department, Government of Pakistan, https://www.tdap.gov.pk/tdapstatistics.php

Viswanathan, P., M.D. Kumar, and A. Narayanamoorthy (2016). Micro Irrigation Systems in India, Emergence, Status and Impact. Springer; New York.

Yin, X., C.F. Seavert, and J. le Roux (2011). Responses of irrigation water use and productivity of sweet cherry to single-lateral drip irrigation and ground covers. Soil Sci. 176:39-47. 